\title{
Konversi Lahan Sawah di Kota Bogor dan Strategi Anggaran dalam Mengendalikannya
}

\section{Wetland Conversion in Bogor City and Budget Strategies Control}

\author{
Oni Hidayati ${ }^{1 *}$, Hermanto Siregar $^{1}$ \& A. Faroby Falatehan ${ }^{1}$ \\ 1Program Studi Manajemen Pembangunan Daerah, Sekolah Pasca Sarjana, Institut Pertanian Bogor, Jl. \\ Kamper Wing 5 Level 4 Kampus IPB Dramaga Bogor 16680; *Penulis korespondensi. e-mail: \\ onihidayati74@gmail.com \\ (Diterima: 4 Juni 2017; Disetujui: 26 Juli 2017)
}

\begin{abstract}
Conversion of agricultural land in urban areas is most prevalent in wetlands, thus threatening food availability and loss of multifunctional land. In the last five years, the wetland area in Bogor City has dropped dramatically to 321 ha (BPS of Bogor City, 2016). Control of the rate of conversion of wetland in Bogor City is regulated by Local Regulation number 8 year 2011 concerning Bogor City Spatial Plan (RTRW Kota Bogor) 2011-2031. However, its implementation is less effective so that there is a need for economic instruments to support it. The purpose of this study is to describe the wetland conversion in Bogor City and budgetary strategies in order to control it. Spatial analysis with overlay method was used to and resulted in a land conversion pattern which was dominated by housing area of $1137.33 \mathrm{ha} \mathrm{(47.08 \% )}$ ) and garden $254.28 \mathrm{ha}$ (10.53\%). The conversion pattern was used as the basis of multiple linear regression analysis of factors affecting wetland area in Bogor City during 2000-2015 which results were: production amount (significant at $\alpha 1 \%$ ); building area (significant at $\alpha 5 \%$ ); realization of Bogor City Agricultural Service budget (not significant) with $R^{2}$ value $=86.6 \%$. Wetland conversion control was conducted through budget strategies which are analyzed with Analitycal Hierrachy Process (AHP) calculation, resulting as follows: (1) socialization budget; (2) budget for formulating local regulation; (3)budget sharing with the central/provincial government; (4) streamlining the role of the private; (5) budget supervision; (6)budget for (land banking); (7) incentives and disincentives for farmers.
\end{abstract}

Keywords: Analitycal Hierrarchy Process (AHP), budget strategy, overlay, wetland protection

\begin{abstract}
ABSTRAK
Konversi lahan pertanian di perkotaan paling banyak terjadi pada lahan sawah, sehingga mengancam ketersediaan pangan dan hilangnya multifungsi lahan. Dalam lima tahun terakhir, luas lahan sawah di Kota Bogor menurun drastis hingga menjadi 320 ha (BPS Kota Bogor, 2016). Pengendalian laju konversi lahan sawah di Kota Bogor diatur oleh Peraturan Daerah (Perda) Nomor. 8 tahun 2011 tentang Rencana Tata Ruang Wilayah (RTRW) Kota Bogor Tahun 2011-2031. Namun, implementasinya kurang efektif sehingga diperlukan instrumen ekonomi untuk mendukungnya. Tujuan penelitian ini adalah untuk mendeskripsikan konversi lahan sawah di Kota Bogor dan strategi anggaran dalam mengendalikannya. Analisis spasial (ArcGIS 10.2) dengan metode overlay menghasilkan pola konversi lahan sawah yang didominasi oleh perumahan seluas 1,137.33 ha (47.08\%) dan kebun sebesar 254.28 ha (10.53\%). Pola konversi tersebut dijadikan dasar analisis regresi linier berganda faktor-faktor yang mempengaruhi luas lahan sawah di Kota
\end{abstract}


Bogor tahun 2000-2015 yang hasilnya adalah: jumlah produksi (signifikan pada $\alpha 1 \%$ ); luas bangunan (signifikan pada $\alpha 5 \%$ ); realisasi anggaran Dinas Pertanian Kota Bogor (tidak signifikan) dengan nilai $\mathrm{R}^{2}=86.6 \%$. Pengendalian konversi lahan sawah dilakukan melalui pemilihan prioritas strategi anggaran perlindungan lahan sawah yang dihasilkan dari perhitungan Analitycal Hierrachy Process (AHP) dengan hasil sebagai berikut: (1) anggaran sosialisasi; (2) anggaran pembuatan Perda; (3) sharing anggaran dengan Pemerintah Pusat/Provinsi; (4) mengefektifkan peranan swasta; (5) anggaran pengawasan; (6) anggaran pembelian lahan (land banking); (7) pemberian insentif dan disinsentif kepada petani.

Kata kunci: Analitycal Hierrarchy Process (AHP), overlay, perlindungan lahan sawah, strategi anggaran

\section{PENDAHULUAN}

\section{Latar Belakang}

Salah satu fenomena yang cukup marak terjadi dalam pemanfaatan lahan adalah konversi lahan. Fenomena ini muncul seiring makin tinggi dan bertambahnya kebutuhan dan permintaan terhadap lahan, baik pertanian maupun nonpertanian akibat pertambahan penduduk dan kegiatan pembangunan. Pada periode lima tahun setelah otonomi daerah, konversi lahan pertanian yang terjadi di Indonesia lebih besar dibandingkan dengan sebelum otonomi daerah (Hidayat, 2008). Jika dilihat dari perbandingan laju konversi lahan sawah dengan laju pertumbuhan penduduk antarkota di Provinsi Jawa Barat pada tahun 2009-2012, Kota Bogor merupakan kota yang memiliki luas konversi lahan sawah dan pertumbuhan penduduk paling tinggi yaitu sebesar 2.54 ha dan 2.42\% (BPS Provinsi Jawa Barat, 2013). Alokasi lahan sawah dalam RTRW Kota Bogor tahun 2011-2031 adalah 600 ha, sedangkan sampai tahun 2014 luas lahan sawah Kota Bogor sebesar 750 ha. Kondisi ini memberikan peluang terjadinya konversi lahan yang tidak terkendali, yang pada akhirnya terjadi penurunan luas lahan sawah di Kota Bogor secara drastis pada tahun 2014-2015 sehingga luasnya hanya sebesar 320 ha (BPS Kota Bogor, 2016). Penurunan luas lahan sawah berakibat penurunan ketersediaan pangan, yang juga disebabkan penurunan produktivitas padi di Kota Bogor pada tahun 2011-2015 secara berurutan adalah: $10.4,8.1,4.2,9.1,3.9$ ton/ha/tahun yang mana dari tahun 2014 ke 2015 menunjukkan penurunan yang sangat drastis (BPS Kota Bogor, 2016).

Secara kasat mata, pola konversi lahan pertanian di perkotaan paling banyak terjadi dari lahan sawah menjadi permukiman dan pertokoan. Akibatnya terancam ketersediaan pangan dan hilangnya multifungsi lahan. Berdasarkan laporan evaluasi RTRW Kota Bogor tahun 2016, luas Ruang Terbuka Hijau (RTH) Kota Bogor masih terpenuhi sebesar 15\%. Sesuai amanah UU Nomor. 41 tahun 2009 tentang Perlindungan Lahan Pertanian Pangan Berkelanjutan dan PP Nomor. 26 tahun 2007 tentang RTRW menjelaskan bahwa syarat ketersediaan Ruang Terbuka Hijau (RTH) adalah sebesar 30\% (20\% publik dan 10\% privat) dari total luas wilayah, maka perlu dilakukan pengendalian konversi lahan sawah di Kota Bogor.

Pengendalian laju konversi lahan pertanian di Indonesia dilakukan dengan beberapa instrumen antara lain: instrumen hukum dan ekonomi, zonasi, dan inisiatif masyarakat. Melalui instrumen hukum, Kota Bogor telah memiliki Perda RTRW tahun 2011-2031, namun implementasinya kurang efektif, oleh karena itu perlu didukung melalui instrument ekonomi dalam hal ini anggaran. Dana merupakan salah satu faktor pengendalian konversi lahan pertanian (Nugraharani, \& Wikarta, 2014). Dana dapat diperoleh melalui anggaran pemerintah maupun kerja sama dengan pihak swasta. Hal yang sama telah dilakukan penelitian oleh Sari (2016) yang mengatakan bahwa strategi dalam meningkatkan Angka Harapan Hidup di Provinsi Jawa Barat adalah melalui 
bantuan keuangan pemerintah ke Kabupaten/ Kota dan kerja sama dengan swasta. Berdasarkan permasalahan tersebut maka pertanyaan dalam penelitian ini adalah "Bagaimanakah fenomena konversi lahan sawah di Kota Bogor dan strategi anggaran dalam mengendalikannya?".

Tujuan penelitian ini adalah: (1) mendeskripsikan fenomena konversi lahan sawah di Kota Bogor pada periode tahun 20002005, 2005-2009, dan 2009-2015; menganalisis faktor-faktor yang mempengaruhi luas lahan sawah di Kota Bogor pada tahun 2000-2015; (3) merumuskan strategi anggaran perlindungan lahan sawah di Kota Bogor.

Ruang lingkup penelitian ini difokuskan pada analisis konversi lahan sawah di Kota Bogor dan strategi anggaran dalam mengendalikannya. Dalam penelitian ini akan diungkapkan faktor-faktor yang berpengaruh terhadap konversi lahan sawah, dilanjutkan dengan perumusan strategi untuk mengendalikannya. Oleh karena itu penelitian ini dilakukan kepada beberapa stakeholders dilingkungan Pemerintah Kota Bogor terkait anggaran pengendalian konversi lahan sawah.

\section{TINJAUAN PUSTAKA}

\section{Konversi Lahan sawah}

Undang-Undang Nomor 41 Tahun 2009 menyebutkan bahwa lahan pertanian adalah bidang lahan yang digunakan untuk usaha pertanian. Lebih lanjut dijelaskan dalam Peraturan Pemerintah Republik Indonesia Nomor 1 Tahun 2011 bahwa kawasan peruntukan pertanian adalah kawasan budidaya yang dialokasikan dan memenuhi kriteria untuk budi daya tanaman pangan, hortikultura, perkebunan, dan/atau peternakan. Lahan pertanian di Indonesia dikelompokkan menjadi lahan pekarangan, tegalan/ladang, sawah, perkebunan, tanaman kayu-kayuan, kolam/tambak, padang rumput, dan lahan yang sementara tidak diupayakan (padang alang-alang dan semak belukar) (BPS Kota Bogor 2016).

Penggunaan lahan oleh manusia untuk tempat tinggal, tempat melakukan usaha, pemenuhan akses umum dan fasilitas lainlainnya disebut konversi lahan. Faktor-faktor yang menyebabkan konversi lahan pertanian antara lain: lemahnya kelembagaan tentang perlindungan lahan pertanian dan kegiatan pembangunan yang berorientasi pada tujuan jangka pendek yaitu peningkatan Pendapatan Asli Daerah (PAD) tanpa memikirkan keberlanjutan multifungsi lahan pertanian (Isa 2006).

Perubahan sosial dan ekonomi masyarakat juga merupakan salah satu faktor yang mempengaruhi konversi lahan pertanian, seperti yang terjadi di Kabupaten Karawang. Pengembangan kawasan industri di Kabupaten Karawang telah menggeser lahan pertanian, hal ini terbukti dengan menurunnya kontribusi sektor pertanian dalam Produk Domestik Regional Bruto (PDRB), sehingga sektor industri menjadi sektor produktif. Sebagai konsekuensinya, terjadi pengurangan lapangan pekerjaan disektor pertanian dan mengancam kapasitas produksi hasil pertanian terutama padi (Syahruddin 2010). Hal ini bertentangan dengan Keppres No. 41 tahun 1996 yang menjelaskan bahwa pembangunan kawasan industri tidak boleh mengurangi tanah pertanian terutama untuk produksi padi. Namun dalam PP No. 24 tahun 2009, pengaturan alih fungsi lahan tidak disebutkan secara tegas, hanya diatur dalam bentuk pengendalian pemanfaatan ruang.

Pengendalian alih fungsi lahan pertanian adalah suatu tindakan tertentu yang dilakukan dengan tujuan agar proses output dan outcomes yang terjadi sesuai dengan yang diharapkan. Langkahlangkah pengendalian alih fungsi lahan pertanian ke non pertanian secara normatif adalah: (1) penentuan cakupan, tujuan, dan sasaran pengendalian lahan yang bertujuan mengamankan kepentingan publik, mengingat pengendalian lahan bersifat spasial maka perlu adanya harmonisasi antara wilayah administrasi sehingga pengendalian lahan merupakan kebijakan lingkup nasional; (2) penentuan pendekatan dengan metode, tergantung tiga aspek yaitu (a) cakupan, tujuan dan sasaran pengendalian alih fungsi lahan pertanian itu sendiri, (b) permasalahan empiris 
yang terkait dengan penyebab, pola, dan dampak alih fungsi lahan pertanian itu dan (c) sumber daya yang dimiliki yang diperkirakan dapat dipergunakan untuk mendukung pendekatan atau metode pengendalian yang akan diterapkan; (3) Identifikasi instrumen kebijakan, sebagai contoh, jika pendekatan yang ditempuh adalah regulasi dan metode yang akan diterapkan adalah zonasi maka instrumen yang sesuai adalah peraturan perundang-undangan, jika pendekatan yang digunakan berupa incentive and charges dan metode yang diterapkan adalah peningkatan insentif pada petani untuk mempertahankan usaha taninya, penentuan instrumen kebijakan harus mempertimbangkan kelayakan teknis, ekonomis, sosial dan politik; (4) implementasi kebijakan, jika langkahlangkah diatas tidak dilaksanakan maka tahap paling krusial tentu saja implementasi dari strategi kebijakan yang telah ditentukan; (5) evaluasi, diperlukan untuk mengukur sejauh mana strategi kebijakan yang telah diterapkan tersebut mencapai sasarannya dan sangat diperlukan untuk memperoleh masukan yang bermanfaat penyempurnaan lebih lanjut. Hal ini mempertimbangkan bahwa secara empiris alokasi lahan merupakan hasil interaksi berbagai faktor yang sangat kompleks. Sejumlah perbaikan harus selalu dilakukan untuk meningkatkan efektivitasnya maupun dalam rangka mengantisipasi dinamika yang dihadapi di lapangan (Deptan, 2005).

\section{Strategi}

Strategi merupakan pola atau rencana yang terintegrasi dari tujuan organisasi, kebijakan-kebijakan strategi yang baik guna membantu menyusun dan menyalurkan sumber daya organisasi secara spesifik dan tahan lama berdasarkan keunggulan dan kelemahan, serta antisipasi perubahan lingkungan dan gerakan lainnya (Mintzberg, 1995).

Strategi muncul karena adanya persaingan pada aspek ekonomi, aspek teknologi, aspek bisnis, dan aspek-aspek lain yang berpotensi untuk menimbulkan persaingan (Porter, 1998). Daya saing merupakan dasar keunggulan suatu kegiatan yang ditentukan oleh kemampuan untuk berkembang dan memahami perubahan pelaku ataupun organisasi atau sistem yang melibatkan kombinasi pemikiran proses serta pemanfaatan efektif dan efisien untuk menghasilkan sesuatu yang berbeda dan lebih unggul daripada pesaing yang lain. Sehingga strategi merupakan seni dan pengetahuan untuk merumuskan, mengimple-mentasikan, dan mengevaluasi keputusan lintas fungsional yang membuat organisasi mampu mencapai tujuannya.

Elemen-elemen strategi dapat dibedakan menjadi seni situasi, tujuan dan sasaran, produk keunggulan kompetitif, pola keputusan, kebijakan dan program, destinasi, sumber daya dan lingkungan, program bertindak, formulasi strategi serta arus keputusan, alat yang paling bahaya dan riskan (deceptive device), dan pemimpin (Salusu, 1996).

Konsep strategi sekurang-kurangnya mencakup 5 (lima) arti yang saling terkait (Mintzberg, 1995), yaitu:

1. Perencanaan untuk semakin memperjelas arah yang ditempuh organisasi secara rasional dalam mewujudkan tujuan-tujuan jangka panjangnya.

2. Acuan yang berkenaan dengan penilaian konsistensi maupun inkonsistensi perilaku serta tindakan yang dilakukan oleh organisasi.

3. Sudut yang diposisikan oleh organisasi saat memunculkan aktivitasnya.

4. Suatu perspektif yang menyangkut visi yang terintegrasi antara organisasi dengan lingkungannya yang menjadi batas bagi aktivitasnya.

\section{Anggaran}

Kusnadi (2002) mengatakan bahwa anggaran adalah estimasi atas penerimaan yang akan diterima dan pengeluaran (biaya) yang akan dikeluarkan terhadap aktivitas yang akan dikerjakan di masa yang akan datang oleh suatu organisasi.

Anggaran sektor publik dibuat untuk membantu menentukan tingkat kebutuhan masyarakat, seperti listrik, air bersih, kualitas 
kesehatan, pendidikan dan sebagainya agar terjamin secara layak. Tingkat kesejahteraan masyarakat dipengaruhi oleh keputusan yang diambil oleh pemerintah melalui anggaran yang mereka buat. Peran anggaran sektor publik dalam pemerintah daerah dapat dilihat dari aspek makro dan aspek mikro. Aspek makro adalah peran anggaran dalam tatanan makro ekonomi, sosial, dan politik suatu daerah. Sedangkan aspek mikro adalah peran anggaran dalam suatu organisasi yang dipandang dari sudut pandang manajerial organisasi (Mahmudi, 2011).

1. Peran anggaran dari aspek makro

Anggaran sektor publik dapat berperan dalam melaksanakan tugas pokok dan fungsi pemerintah, yaitu melakukan alokasi, distribusi, dan stabilisasi.

a. Anggaran sebagai alat alokasi, yaitu alokasi anggaran berdasarkan urusan, alokasi berdasarkan fungsi, alokasi berdasarkan organisasi, dan alokasi berdasarkan program.

1. alokasi berdasarkan urusan: urusan pemerintahan adalah fungsi-fungsi pemerintahan yang menjadi hak dan kewajiban setiap tingkatan dan/atau susunan pemerintahan untuk mengatur dan mengurusi fungsi-fungsi yang menjadi kewenangannya dalam rangka melindungi, melayani, memberdayakan, dan menyejahterakan masyarakat. Alokasi anggaran berdasarkan urusan menetapkan berapa anggaran untuk belanja pelaksanaan urusan wajib (seperti pendidikan, kesehatan, pekerjaan umum, dan sebagainya) dan berapa anggaran untuk urusan pilihan (seperti pertanian, kehutanan, pariwisata, dan lain-lain).

2. alokasi berdasarkan fungsi, meliputi: pelayanan umum, ketertiban dan ketentraman, ekonomi, kesehatan, pendidikan, dan sebagainya.

3. alokasi berdasarkan organisasi: anggaran dialokasikan sesuai dengan struktur organisasi yang ada. Unit organisasi pemerintah daerah berupa Satuan Kerja Pemerintah Daerah (SKPD)
4. alokasi berdasarkan program: dapat berupa plafon anggaran untuk setiap program kerja.

b. anggaran sebagai alat distribusi, yaitu untuk mendistribusikan pendapatan atau sumber daya publik agar terjadi pemerataan dan keadilan ekonomi. Mekanisme distribusi dilakukan dalam bentuk pemberian subsidi kepada masyarakat dan melalui program-program pro-rakyat.

c. Anggaran sebagai alat stabilisasi, yaitu untuk menciptakan stabilitas ekonomi, sosial, dan politik. Stabilisasi dilakukan melalui kebijakan fiskal, bantuan sosial, dana bencana, dan lainlain.

2. Peran anggaran dari aspek mikro

a. Anggaran sebagai alat perencanaan

Anggaran sebagai alat perencanaan berisi estimasi pendapatan yang akan diterima dan pengeluaran yang akan dilakukan selama periode anggaran. Anggaran berfungsi menyelaraskan perencanaan jangka pendek dengan perencanaan jangka panjang.

b. Anggaran sebagai alat pengendalian Sebagai alat pengendalian, anggaran dapat digunakan untuk memantau tingkat capaian kinerja organisasi.

c. Anggaran sebagai alat koordinasi dan komunikasi

Anggaran dapat berfungsi sebagai alat untuk mengkoordinasikan berbagai bagian organisasi dalam proses perencanaan, pelaksanaan, dan pertanggungjawaban anggaran. Anggaran juga dapat berperan sebagai alat komunikasi antara atasan dan bawahan dan antar unit kerja. Komunikasi juga dapat dilakukan antara legislatif dan eksekutif.

d. Anggaran sebagai alat penilaian kinerja Organisasi atau manajer dinilai kinerjanya berdasarkan realisasi dengan target anggaran. Penilaian kinerja anggaran pada umumnya menggunakan analisis selisih (varians) 
e. Anggaran sebagai alat motivasi

Anggaran dapat berfungsi sebagai alat motivasi jika pencapaian target tidak sesuai dengan perencanaan, misalnya dengan adanya insentif, bonus, dan kompensasi yang berbentuk keuangan atau penghargaan sosial dan psikologis yang bersifat non keuangan atas prestasi yang telah dicapai.

Penganggaran adalah proses atau metode untuk mempersiapkan anggaran yang merupakan proses penentuan jumlah alokasi dana untuk tiap-tiap program dan aktivitas dalam satuan moneter (Mardiasmo, 2002). Tujuan perencanaan pengeluaran adalah untuk menjamin bahwa sustu keputusan yang menyangkut pengalokasian dana yang terbatas, harus mempertimbangkan beberapa hal antara lain: prioritas kebutuhan dan akibat yang akan timbul (perekonomian secara keseluruhan misalnya inflasi) (Kunarjo, 2002).

\section{Anggaran Pendapatan Belanja Daerah (APBD)}

Berdasarkan Peraturan Menteri Dalam Negeri Nomor 21 Tahun 2011 tentang Perubahan Kedua Atas Peraturan Menteri Dalam Negeri Nomor 13 tahun 2006 tentang Pedoman Pengelolaan Keuangan Daerah, dalam konteks pengelolaan keuangan daerah Anggaran Pendapatan dan Belanja Daerah, selanjutnya disingkat APBD adalah rencana keuangan tahunan pemerintahan daerah yang dibahas dan disetujui bersama oleh pemerintah daerah dan DPRD, dan ditetapkan dengan peraturan daerah. APBD disusun sesuai dengan kebutuhan penyelenggaraan pemerintahan dan kemampuan pendapatan daerah berdasarkan rencana pendapatan dan rencana belanja program dan kegiatan dinas/badan/lembaga sebagai satuan kerja perangkat daerah (SKPD).

Beberapa fungsi APBD antara lain: fungsi otorisasi, perencanaan, pengawasan, alokasi, distribusi, dan stabilisasi. Fungsi otorisasi mengandung arti bahwa anggaran daerah menjadi dasar untuk melaksanakan pendapatan dan belanja pada tahun yang bersangkutan. Fungsi perencanaan mengandung arti bahwa anggaran daerah menjadi pedoman bagi manajemen dalam merencanakan kegiatan pada tahun yang bersangkutan. Fungsi pengawasan mengandung arti bahwa anggaran daerah menjadi pedoman untuk menilai apakah kegiatan penyelenggaraan pemerintahan daerah sesuai dengan ketentuan yang telah ditetapkan. Fungsi alokasi mengandung arti bahwa anggaran daerah harus diarahkan untuk menciptakan lapangan kerja mengurangi pengangguran dan pemborosan sumber daya, serta meningkatkan efisiensi dan efektitivitas perekonomian. Fungsi distribusi mengandung arti bahwa kebijakan anggaran daerah harus memperhatikan rasa keadilan dan kepatutan. Fungsi stabilisasi mengandung arti bahwa anggaran pemerintah daerah menjadi alat untuk memelihara dan mengupayakan keseimbangan fundamental perekonomian daerah.

\section{METODE PENELITIAN}

\section{Jenis dan Sumber Data}

Data yang digunakan dalam penelitian ini merupakan data primer dan sekunder. Data primer berupa peta landuse Kota Bogor tahun 2000, 2005, 2009, dan 2015 dan hasil kuesioner Analytical Hierrarchy Process (AHP). Data sekunder berupa data deret waktu (time series) tahun 2000-2015. Data diperoleh dari berbagai sumber yakni Badan Perencanaan Pembangunan Daerah (Bappeda) Kota Bogor, Badan Pusat Statistik (BPS) Kota Bogor, Dinas Pertanian (Distani) Kota Bogor dan Badan Pendapatan Daerah (Bapenda) Kota Bogor.

\section{Metode Analisis Data}

Penelitian ini menggunakan metode analisis kualitatif (deskriptif) dan analisis kuantitatif. Metode analisis kualitatif (deskriptif) yang digunakan dalam penellitian ini adalah analisis spasial (ArcGIS 10.2). Metode analisis kuantitatif yang digunakan dalam penelitian ini terdiri atas dua analisis, yaitu analisis regresi linier berganda dan AHP.

Metode analisis spasial (ArcGIS) dengan metode overlay peta landuse Kota Bogor tahun 
2000-2005, 2005-2009, dan 2009-2015 bertujuan untuk memberikan gambaran serta menganalisis pola konversi lahan sawah di Kota Bogor. Metode analisis regresi linier berganda didasarkan pada metode Ordinary Least Square (OLS), yang bertujuan menganalisis faktorfaktor yang mempengaruhi luas lahan sawah di Kota Bogor seperti yang dilakukan oleh Putri (2015). Untuk menentukan faktor-faktor apa saja yang akan digunakan untuk analisis regresi, didasarkan pada pola konversi lahan sawah yang dihasilkan dari analisis GIS peta land use Kota Bogor dengan metode overlay.

Adapun model persamaan yang digunakan adalah model logaritma natural sebagai berikut (Gujarati, 2002):

$L n L L S_{t}=\beta_{0}+\beta_{1} L n J P_{t}+\beta_{2} L n R A D_{t}+\beta_{3} L_{n J P D_{t}}$ $+\beta_{3} \operatorname{LnPDRB_{t}}+\beta_{3} \operatorname{LnLB_{t}}+\varepsilon_{t}$

Keterangan :

$\begin{array}{ll}\text { LnLLS }_{\mathrm{t}} & =\text { Luas Sawah (Ha) } \\ \text { LnJP }_{\mathrm{t}} & =\text { Jumlah Produksi (ton) } \\ \text { LnRAD }_{\mathrm{t}} & =\text { Realisasi Anggaran Dinas } \\ & \text { Pertanian Kota Bogor (juta Rp) } \\ \text { LnJPD }_{\mathrm{t}} & =\text { Jumlah Penduduk (juta jiwa) } \\ \text { LnPDRB }_{\mathrm{t}} & =\text { Jumlah PDRB (juta Rp) } \\ \text { LnLB }_{\mathrm{t}} & =\text { Luas Bangunan (Ha) } \\ \text { Hipotesis } & =\beta_{1} \text { dan } \beta_{2}>0 ; \\ & \beta_{3,}, \beta_{4} \text {, dan } \beta_{5}<0\end{array}$

Penentuan alternatif strategi anggaran perlindungan lahan sawah merupakan salah satu langkah untuk menentukan tindakan atau program apa yang berperan dalam mengendalikan konversi lahan sawah di Kota Bogor. Alternatif strategi anggaran, stakeholder, dan kendala perlindungan lahan sawah ini dihimpun dari UU Nomor. 41 tahun 2009 tentang Perlindungan Lahan Pertanian Pangan Berkelanjutan, PP Nomor. 1 Tahun 2011 tentang Penetapan dan Alih Fungsi Lahan Pertanian Pangan Berkelanjutan, PP Nomor. 12 tahun 2012 tentang Insentif, PP Nomor. 30 tahun 2012 tentang Pembiayaan Perlindungan LP2B, Perda Nomor. 8 tahun 2011 tentang RTRW Kota Bogor Tahun 2011-2031, RPJMD Kota Bogor Tahun 2014-2019, UU Nomor. 1 tahun 2004 tentang anggaran, PP Nomor. 190 tahun 2012 tentang APBN, Peraturan Menteri Dalam Negeri
(Permendagri) Nomor 21 tahun 2011 tentang APBD, Peraturan Walikota (Perwali) Kota Bogor tentang penjabaran anggaran, dan laporan kegiatan dan pertanggungjawaban Dinas Pertanian Kota Bogor tahun 2016. Adapun faktor pertimbangan yang mempengaruhi keberhasilan alternatif strategi dihimpun berdasarkan faktor-faktor yang berpengaruh terhadap luas lahan sawah hasil dari analisis regresi linier berganda.

Pemilihan prioritas strategi anggaran perlindungan lahan sawah dilakukan dengan menggunakan metode AHP. Rofiqi et al. (2016) dalam penelitiannya mengatakan bahwa metode yang digunakan dalam memprioritaskan strategi percepatan pengembangan industri turunan minyak sawit mentah (MSM) di Indonesia menggunakan metode AHP. Pengisian kuesioner dilakukan melalui wawancara tertutup, yang digunakan untuk memilih prioritas strategi anggaran perlindungan lahan sawah di Kota Bogor. Penentuan responden dilakukan metode purposive sampling sebanyak 10 responden. Dalam metode ini digunakan teknik perbandingan berpasangan dengan nilai komparasi/pembobotan antara 1 sampai 9. Skala perbandingan tersebut adalah: 1 = sama penting; $3=$ sedikit penting; $5=$ lebih penting; $7=$ jauh lebih penting; 9 = sangat lebih penting; dan $2,4,6,8=$ nilai antara (Saaty, 1993). Nilai total diperoleh melalui perhitungan bobot dari masing-masing faktor pada setiap level dalam hierarki.

\section{HASIL DAN PEMBAHASAN}

\section{Pola Konversi Lahan}

Pola konversi lahan menggambarkan perubahan penggunaan lahan akibat pemanfaatan lahan untuk kepentingan manusia. Luas lahan sawah di Kota Bogor pada tahun 2000 seluas 2,662.61 ha, sedangkan pada tahun 2015 seluas 316.21 ha, hal ini berarti luas lahan sawah tersebut telah terkonversi seluas 2,346.4 ha atau $88.12 \%$. Pola konversi lahan sawah di Kota Bogor ditunjukkan dalam Tabel 1. Pola konversi lahan sawah di Kota Bogor pada tiga periode waktu (tahun 2000-2005, 2005-2009, dan 2009- 
2015), secara berurutan didominasi oleh ladang dan kebun untuk lahan non bangunan, sedangkan untuk lahan bangunan didominasi oleh permukiman dan perumahan. Jika dilihat dari tahun 2000-2015, pola konversi lahan sawah di Kota Bogor di dominasi oleh kebun sebesar $47.08 \%$ (lahan non bangunan) dan perumahan sebesar $10.53 \%$ (lahan bangunan).

Tabel 1. Pola konversi lahan sawah di Kota Bogor

\begin{tabular}{|c|c|c|c|c|c|c|}
\hline \multirow{2}{*}{ No. } & \multirow{2}{*}{ Pola Perubahan } & \multicolumn{4}{|c|}{ Tahun Perubahan (Ha) } & \multirow{2}{*}{$\begin{array}{c}\text { Perubahan } \\
(\%)\end{array}$} \\
\hline & & $2000-2005$ & $2005-2009$ & 2009-2015 & $2000-2015$ & \\
\hline 1 & Gardu Listrik & & 0.00 & & 0.00 & 0.00 \\
\hline 2 & Hutan Kota & & 0.21 & & 0.21 & 0.01 \\
\hline 3 & Industri & & 0.25 & 0.00 & 0.25 & 0.01 \\
\hline 4 & Kebun & & 145.48 & 991.85 & $\mathbf{1 , 1 3 7 . 3 3}$ & 47.08 \\
\hline 5 & Kolam & 0.13 & 23.48 & 5.69 & 29.29 & 1.21 \\
\hline 6 & Komplek Militer & & 0.17 & & 0.17 & 0.01 \\
\hline 7 & Ladang & 0.13 & 212.97 & & 213.10 & 8.82 \\
\hline 8 & Lapangan olahraga & & 10.20 & & 10.20 & 0.42 \\
\hline 9 & $\begin{array}{l}\text { Perdagangan dan } \\
\text { jasa }\end{array}$ & 0.01 & 0.03 & & 0.03 & 0.00 \\
\hline 10 & Permukiman & 2.97 & 61.76 & 114.29 & 179.01 & 7.41 \\
\hline 11 & Perumahan & 0.26 & 36.53 & 217.49 & 254.28 & 10.53 \\
\hline 12 & RTH & 8.35 & 160.95 & & 169.30 & 7.01 \\
\hline 13 & Semak & 0.87 & 52.54 & 66.37 & 119.79 & 4.96 \\
\hline 14 & Situ & & 1.15 & & 1.15 & 0.05 \\
\hline 15 & DAS/Sungai & 60.51 & 4.62 & & 65.13 & 2.70 \\
\hline 16 & Taman & & 0.11 & 17.95 & 18.06 & 0.75 \\
\hline 17 & Tanah Kosong & 0.39 & 132.79 & 27.58 & 160.76 & 6.65 \\
\hline 18 & Terminal & & 0.48 & & 0.48 & 0.02 \\
\hline 19 & TPU & & 2.60 & & 2.60 & 0.11 \\
\hline 20 & Jalan & & & 54.67 & 54.67 & 2.26 \\
\hline 21 & Pendidikan & 0.01 & & & 0.01 & 0.00 \\
\hline & Total & 73.62 & 846.31 & $1,495.90$ & $2,415.82$ & 100.00 \\
\hline
\end{tabular}

Sumber : Hasil Penelitian, 2017

Pola perubahan ini sesuai dengan hasil kajian Bappeda Kota Bogor (2015) bahwa komposisi permukiman swadaya (pemukiman) sebesar $31.83 \%$ dan permukiman terstruktur (perumahan) sebesar $10.13 \%$ dari total luas wilayah Kota Bogor. Hal ini dapat disimpulkan hampir semua lahan perumahan di Kota Bogor berasal dari lahan sawah yang di konversi. Lahan pertanian terdiri atas sawah, tegal/kebun, ladang, dan ladang yang sementara tidak diusahakan (BPS, 2016). Berdasarkan Tabel 1. kebun mendominasi pola konversi lahan sawah non bangunan sebesar $1,137.37$ ha (47.03\%), hal ini sesuai dengan data BPS pada tahun 2011-2015, di mana luas kebun semakin meningkat sedangkan luas sawah, ladang, ladang yang sementara tidak diusahakan dan lainnya semakin menurun.
Adapun konversi lahan sawah menjadi kebun di Kota Bogor pada periode tahun 2005-2012 sebesar 372.8 ha (Mayasary, 2015). Hal ini dapat disimpulkan bahwa pada periode tahun 2012-2015 konversi lahan sawah menjadi kebun meningkat tajam sebesar 764.57 ha.

\section{Faktor-Faktor yang Berpengaruh terhadap Luas Lahan Sawah di Kota Bogor}

Berdasarkan hasil analisis regresi linier berganda dari variabel-variabel bebas dan terikat diperoleh suatu model yang telah dimodifikasi sedemikian rupa sehingga didapatkan model terbaik sebagai berikut:

Luas Lahan Pertanian (ha) $=11.3-0.395$ Jumlah Produksi (ton) + 0.0923 Realiasasi Anggaran Dinas Pertanian Kota Bogor (Rp) - 0.228 Luas Bangunan (ha). 
Tabel 2. Hasil estimasi model faktor-faktor yang mempengaruhi luas lahan sawah

\begin{tabular}{llllrrr}
\hline No & \multicolumn{1}{c}{ Variabel Bebas } & \multicolumn{1}{c}{ Coef } & SE Coef & T & P & VIF \\
\hline JP & Jumlah Produksi (ton) & $0.39520^{*}$ & 0.13430 & 2,94 & 0,012 & 1.136 \\
RAD & Realisasi Anggaran & 0.09231 & 0.07358 & 1.25 & 0.234 & 2.225 \\
& Distani (Rp Juta) & & & & & \\
LB & Luas Bangunan (ha) & $-0.22796^{* *}$ & 0.03598 & -6.34 & 0.000 & 2.107 \\
C & Konstanta & 11.331 & 1.467 & & & \\
\hline & R-Square & $86,6 \%$ & & & & \\
& F-statistic & $25.94^{* *}$ & & & 0.000 & \\
& Durbin-Watson & 1,32738 & & & &
\end{tabular}

Sumber : Hasil Penelitian, 2017

keterangan: $* *=$ signifikan pada $\alpha=1 \%$

* = signifikansi pada $\alpha=5 \%$

Tabel 2. menunjukkan nilai koefisien determinasi atau $R$-square sebesar $86.6 \%$. Hal ini berarti semua variabel bebas (produksi, anggaran Dinas Pertanian Kota Bogor, dan luas bangunan) dapat menjelaskan variabel terikat (luas lahan sawah) sebesar $86.6 \%$. Sedangkan sisanya sebesar $13.4 \%$ ditentukan atau jelaskan oleh variabel lain di luar variabel model yang telah ditetapkan. Nilai $\mathrm{F}$ hitung model sebesar 25.94 signifikan pada taraf $1 \%$ menunjukkan bahwa variabel produksi berpengaruh secara positif dan signifikan terhadap variabel luas lahan sawah, sedangkan variabel luas bangunan berpengaruh secara negatif dan signifikan terhadap variabel luas lahan sawah.

Hal ini terjadi juga di Kecamatan Somba Opu Kabupaten Gowa yang mana penurunan produksi berpengaruh positif dan signifikan terhadap alih fungsi lahan atau dengan kata lain berpengaruh negatif terhadap luas lahan $\left(\mathrm{R}^{2}=1\right)$ (Syaifuddin et al., 2013). Adapun yang terjadi di pinggiran Kota Yogyakarta, luas bangunan berpengaruh positif dan signifikan terhadap laju konversi lahan pertanian (Sudirman et al., 2010).

Variabel anggaran Dinas Pertanian berpengaruh secara positif dan tidak signifikan terhadap variabel luas lahan sawah. Berdasarkan Dokumen Pelaksanaan Anggaran (DPA) bidang Tanaman Pangan dan Hortikultura (TPH) Dinas Pertanian tahun 2015, persentase dari kegiatan Dinas Pertanian yang digunakan untuk mendukung peningkatan produksi sawah sangat kecil dan kurang tepat sasaran. Beberapa kegiatan yang mengarah ke pemberian insentif kepada petani seperti pelatihan, pupuk, alat dan mesin pertanian (alsintan), pengadaan irigasi dan lain-lain diperkirakan 35\% dari anggaran bidang TPH, dan 10\% dari Anggaran Dinas Pertanian.

Konstanta sebesar 11.331 menunjukkan bahwa jika tidak terdapat kenaikan atau penurunan dari nilai faktor-faktor yang mempengaruhi luas lahan sawah maka luas lahan berada pada angka 11.331. Luas lahan akan meningkat atau menurun jika terdapat perubahan pada ketiga variabel bebas. Koefisien variabel jumlah produksi sebesar 0.3952, menerangkan bahwa peningkatan produksi sebesar $1 \%$ akan meningkatkan luas lahan sawah sebesar $0.3952 \%$ sedangkan koefisien variabel luas bangunan sebesar -0.22796 , menerangkan bahwa peningkatan luas bangunan sebesar $1 \%$ akan menurunkan luas lahan sawah sebesar $0.22796 \%$.

Berdasarkan hasil analisis spasial (Tabel 1), pola konversi lahan sawah di Kota Bogor didominasi oleh perumahan. Ironisnya, berdasarkan analisis backlog (kebutuhan rumah), pada tahun 2013 Kota Bogor tidak memiliki backlog, namun justru kelebihan jumlah rumah sebesar 58.280 unit.

Proyeksi kelebihan rumah Kota Bogor berdasarkan proyeksi jumlah kepala keluarga (KK) pada tahun 2031 sebesar 15,662 unit (Bappeda, 2015). 


\section{Perumusan Alternatif Strategi Anggaran Perlindungan Lahan Sawah di Kota Bogor dengan Metode AHP}

Berdasarkan hasil analisis regresi linier berganda yaitu faktor-faktor yang berpengaruh terhadap luas lahan sawah, dapat disusun struktur hirarki anggaran perlindungan lahan sawah di Kota Bogor. Struktur hirarki yang menerangkan hubungan antara tujuan, faktor pertimbangan, stakeholders, kendala dan alternatif strategi ditunjukkan pada Gambar 1 .

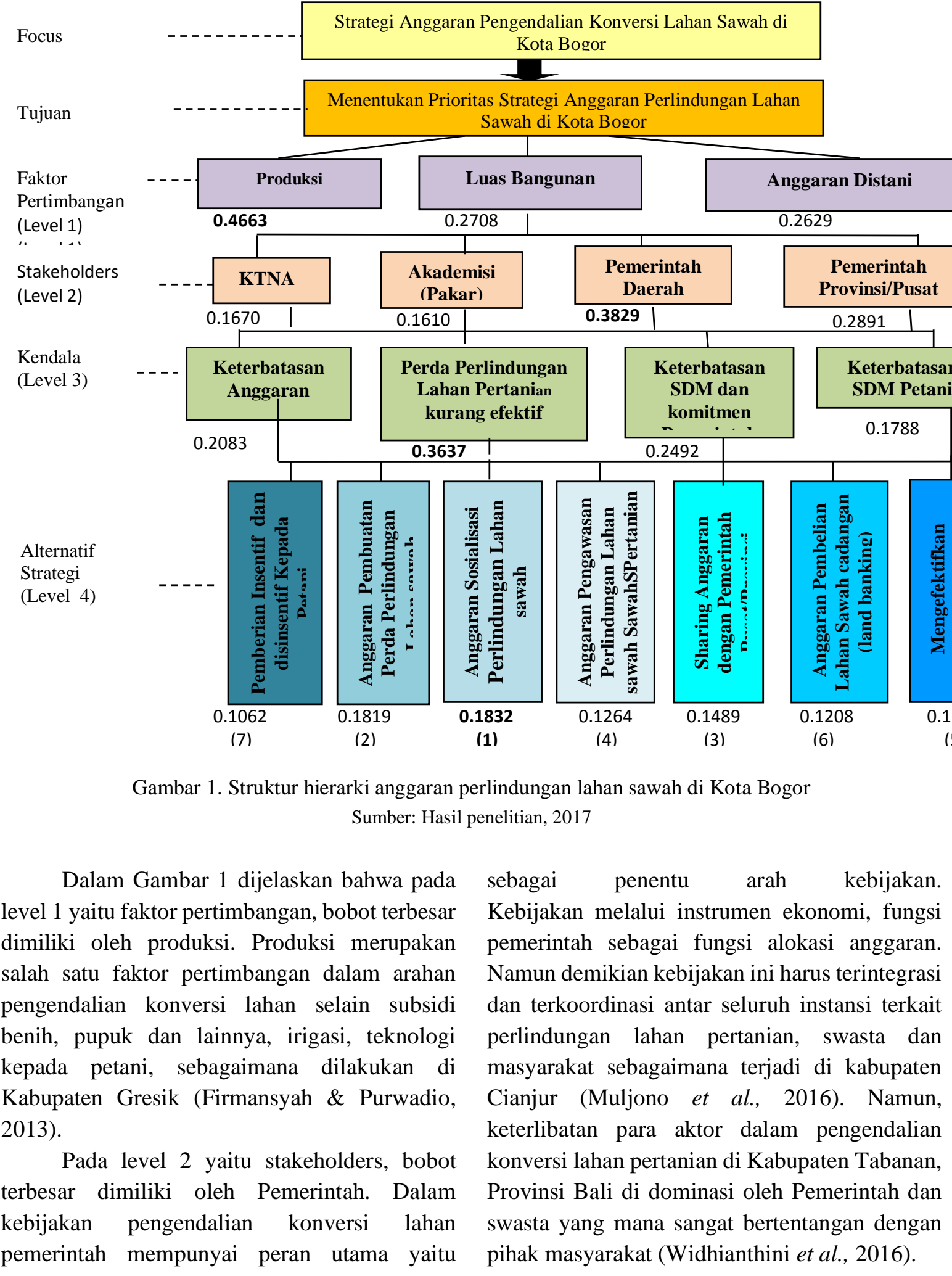


Namun, keterlibatan para aktor dalam pengendalian konversi lahan pertanian di Kabupaten Tabanan, Provinsi Bali di dominasi oleh Pemerintah dan swasta yang mana sangat bertentangan dengan pihak masyarakat (Widhianthini et al., 2016).

Pada level 3 yaitu kendala, bobot terbesar dimiliki oleh Perda perlindungan lahan pertanian yang kurang efektif. Perlindungan lahan pertanian di Kota Bogor diatur dalam Perda RTRW Kota Bogor tahun 2011-2031, tetapi tidak terlaksana secara efektif. Hal ini disebabkan oleh ketidakjelasan sangsi dan area lahan sawah tidak termasuk kawasan lindung dalam peta RTRW Kota Bogor tahun 20112031. Lemahnya implementasi Perda tersebut disebabkan tidak ada komitmen pemerintah yang kuat dan kurangnya peran masyarakat dalam mendukung perlindungan lahan pertanian sperti yang terjadi di Kabupaten Demak (Widayati, 2015). Keberpihakan pemerintah terhadap masyarakat petani dalam pelaksanaan percepatan pembangunan di suatu perkotaan terutama daerah hollowing village di Vietnam, dengan mengkonversi lahan pertanian diharapkan melalui pendekatan ekonomi yaitu pemilihan sumber daya alam yang ada dengan memperhatikan pendapat atau hak-hak petani (Well-Dangs et al., 2016).

Hasil perhitungan menggambarkan prioritas alternatif strategi anggaran yang mana bobot paling tinggi merupakan prioritas utama strategi anggaran perlindungan lahan sawah di Kota Bogor. Berdasarkan urutan pembobotan dari yang terbesar sampai yang terkecil, dihasilkan urutan prioritas strategi sebagai berikut : (1) anggaran sosialisasi perlindungan lahan sawah; (2) anggaran pembuatan perda perlindungan lahan sawah; (3) sharing anggaran dengan Pemerintah Pusat/Provinsi; (4) mengefektifkan peranan swasta; (5) anggaran pengawasan lahan sawah; (6) anggaran pembelian lahan sawah (land banking); (7) pemberian insentif dan disinsentif.

Dinas Pertanian Kota Bogor sudah pernah melakukan kegiatan sosialisasi pada anggaran tahun 2012, tetapi implementasinya tidak efektif, hal ini terbukti dengan semakin berkurangnya lahan sawah di Kota Bogor. Ketidakefektifan sosialisasi disebabkan ketidak-jelasan peraturan daerah yang mengatur tentang perlindungan lahan sawah seperti yang terjadi di Kabupaten Bojonegoro (Keiky, 2016). Sosialisisasi yang intensif dan kontinyu kepada masyarakat serta koordinasi antar instansi merupakan faktor utama keberhasilan implementasi perlindungan lahan pertanian pangan berkelanjutan. Di Provinsi Riau, sosialisasi perlindungan lahan pertanian dilakukan melalui penyuluhan, bimbingan, dan pelatihan (Gevisioner \& Riza, 2014). Lebih lanjut dijelaskan dalam rangka meningkatkan perlindungan lahan pertanian dilakukan sosialisasi terhadap stakeholder (Irawan, 2014), dalam hal ini termasuk instansi pemerintah agar mempunyai satu konsep pemikiran tentang pentingnya lahan pertanaian. Dengan demikian diperlukan penganggaran sosialisasi melalui program dan kegiatan yang efektif dan tepat sasaran.

Pemerintah Kota Bogor menunjukkan komitmennya untuk ikut dalam pengendalian alih fungsi lahan pertanian dengan menerbitkan Peraturan Daerah Nomor. 8 tahun 2011 tentang RTRW Kota Bogor tahun 2011-2031 tetapi terasa tumpul. Di dalam Perda RTRW hanya menyebutkan luas lahan sawah yang dilindungi sebesar $600 \mathrm{~m}^{2}$ tetapi tidak digambarkan sebagai kawasan lindung di dalam peta RTRW. Pada kenyataannya luas lahan sawah di Kota Bogor pada tahun 2015 berubah menjadi 320 ha (BPS Kota Bogor, 2016). Mengenai aturan konversi dan sangsi pelanggaran penggunaan lahan sawah tidak dijelaskan di dalam perda RTRW. Dalam rangka menggambarkan peta lahan sawah yang dilindungi, sebaiknya dituangkan dalam peta RTRW atau dalam RDTR (Rencana Detail Tata Ruang).

Aspek perencanaan dan penetapan Lahan Pertanian Pangan Berkelanjutan (LP2B) dan Lahan Cadangan Pertanian Pangan Berkelanjutan (LCP2B) seharusnya ditempatkan pada RDTR dan bukan pada RTRW kota/kabupaten (Bappenas, 2015). Salah satu faktor pendorong alih fungsi lahan sawah adalah lemahnya kelembagaan dan lemahnya implementasi RDTR (Dewi \& Sarjana, 2015). 
Dalam rangka melindungi lahan pertanian, pemerintah mengeluarkan UU Nomor. 41 tahun 2009 tentang Perlindungan Lahan Pertanian Pangan Berkelanjutan (LP2B). Untuk menerbitkan Perda LP2B pemerintah membutuhkan anggaran yang digunakan untuk membiayai beberapa langkah proses mulai dari perencanaan sampai ke sangsi administrasi. Pada tahap perencanaan dilakukan melalui kegiatan pemetaan lahan sawah yang bertujuan menentukan lahan sawah yang akan di jadikan LP2B dengan penegakan sanksi bagi pelanggar (Setiawan \& Purwadio, 2013). Selanjutnya dilakukan penelitian sampai pelaksanaan perda perlindungan LP2B di kota/kabupaten dengan pembiayaan pemerintah. Salah satu daerah yang sudah memiliki LP2B dan melakukan penelitian bersumber dari APBD adalah Kabupaten Tabanan, Bali (Bappenas, 2015). Dengan demikian pemerintah Kota Bogor harus melakukan penganggaran pembuatan Perda LP2B secara bertahap dan terencana.

Keterbatasan anggaran merupakan faktor mutlak yang dihadapi setiap pemerintah dalam melaksanakan program pembangunan. Laporan kegiatan Dinas Pertanian Kota Bogor, selama ini anggaran bidang pertanian berasal dari dana dekonsentrasi Provinsi Jawa Barat dan Tugas Pembantuan (TP) berupa alat dan mesin pertanian. Berdasarkan Perda Nomor. 41 tahun 2009 tentang LP2B, pembiayaan pengelolaan lahan bisa diusahakan melalui sharing dengan Pemerintah Pusat atau Provinsi bahkan bekerjasama dengan pihak swasta. Karena keterbatasan anggaran pemerintah, Kabupaten Maros dan Garut bekerja sama dengan investor dalam pengelolaan LP2B (Bappenas, 2015). Seharusnya pemerintah Kota Bogor dapat lebih komitmen dalam pemanfaatan dana untuk melaksanakan program dan kegiatan yang mendukung perlindungan lahan sawah.

Penganggaran pengawasan lahan pertanian di Kota Bogor tercakup dalam tugas pokok dan fungsi (tupoksi) Dinas Perumahan dan Pemukiman. Untuk mengoptimalkan pengawasan diperlukan koordinasi dengan seluruh instansi pemerintah terutama Dinas Pertanian Kota Bogor, Bidang Sumberdaya Air (SDA)
Dinas Pekerjaan Umum dan Penataan Ruang Kota Bogor, Dinas Perumahan dan Pemukiman Kota Bogor dan Badan Pelayanan Perijinan Terpadu dan Penanaman Modal (BPPTPM) Kota Bogor. Pengawasan dilakukan melalui kebijakan pengendalian konversi lahan yang holistik dan komprehensif, salah satunya adalah pengketatan perizinan. Intensitas pengawasan lahan sawah yang mempunyai cost opportunity tinggi, memerlukan pengawasan yang ketat karena sangat memungkinkan untuk di konversi dalam rangka meningkatkan pendapatan petani. Arahan kegiatan pengawasan terhadap perlindungan lahan sawah dilakukan melalui penertiban bangunan di atas lahan sawah (Pradana \& Pamungkas, 2013). Oleh karena itu diperlukan penganggaran untuk pelaksanaan program dan kegiatan peningkatan kemampuan dan tanggungjawab Sumberdaya manusia (SDM) pengawasan perlindungan lahan sawah.

Strategi yang keenam adalah pembelian lahan sawah sebagai lahan cadangan pertanian oleh pemerintah (land banking), yaitu membeli lahan sawah masyarakat untuk lahan pertanian pangan berkelanjutan (LP2B). Berdasarkan laporan hasil studi banding panitia khusus (pansus) lahan pertanian DPRD Kota Bogor ke Kota Malang pada tahun 2017 adalah sebesar 16 ha sawah dibeli oleh Pemerintah dan dijadikan LP2B. Dalam hal ini, lahan cadangan dapat digunakan untuk ditetapkan sebagai lahan LP2B atau menambah LP2B. Pemerintah Kota Bogor diharapkan dapat menganggarkan dana setiap tahun untuk membeli lahan sawah diluar lahan yang ditetapkan sebagai LP2B sehingga dapat menambah jumlah lahan sawah yang dilindungi.

Pemberian insentif dan disinsentif kepada petani merupakan strategi anggaran perlindungan lahan pertanian yang terakhir. Salah satu kegiatan pemberian insentif kepada petani di Kota Bogor adalah keringanan pajak sawah sebesar 75\%. Negara Cina dan Vietnam telah berhasil dalam pemberian insentif yaitu melalui intervensi pemerintah dalam berinvestasi pada teknologi pemuliaan padi dan pembangunan infrastruktur, seperti reformasi sistem pertanian adopsi padi hibrida dan investasi irigasi. Sementara pembebasan ekspor beras premium 
dan penyediaan kredit di tahun 1980-an telah membantu Thailand untuk menjadi eksportir beras terbesar (Xie dan Napasintuwong 2014). Berdasarkan laporan pertanggung-jawaban Dinas Pertanian Kota Bogor, pemberian insentif sebagian sudah dilakukan oleh Dinas Pertanian Kota Bogor melalui Anggaran Pendapatan dan Belanja Daerah (APBD), APBD Dinas Pertanian Provinsi Jawa Barat, Tugas Pembantuan (TP) dari Kementerian Pertanian dan Bidang Irigasi Dinas Pekerjaan Umum dan Penataan Ruang (PUPR) Kota Bogor. Meskipun pemberian insentif tersebut sudah dilakukan, berdasarkan Dokumen Pelaksanaan Anggaran (DPA) Dinas pertanian Kota Bogor, insentif tidak secara rutin diberikan dan tidak cukup untuk memenuhi kebutuhan seluruh petani di Kota Bogor. Arahan pemberian insentif dan disinsentif dapat lebih difokuskan dan ditingkatkan melalui pengelolaan anggaran Dinas Pertanian Kota Bogor.

\section{KESIMPULAN DAN REKOMENDASI}

Hasil overlay peta penggunaan lahan sawah pada tahun 2000-2005, 2005-2009, dan 2009-2015, secara berurutan jumlah lahan sawah yang terkonversi sebesar $2.77 \%, 31.84 \%$, dan 82.56\%. Pola konversi lahan sawah secara berurutan dari tiga periode tersebut didominasi oleh pemukiman dan ladang, perumahan dan ladang, dan perumahan dan kebun. Secara keseluruhan luas lahan sawah yang terkonversi dari tahun 2000-2015 yaitu sebesar 88.12\% dan pola konversi yang paling besar adalah perumahan dan kebun.

Hasil analisis regresi linier berganda, faktor-faktor yang berpengaruh positif dan signifikan terhadap konversi lahan sawah di Kota Bogor adalah jumlah produksi, sedangkan yang berpengaruh negatif dan signifikan adalah luas bangunan. Faktor yang berpengaruh positif tetapi tidak signifikan adalah realisasi anggaran Dinas Pertanian Kota Bogor.

Prioritas strategi anggaran perlindungan lahan pertanian sawah menurut metode AHP adalah sebagai berikut: (1) anggaran sosialisasi lahan sawah; (2) anggaran pembuatan perda
LP2B; (3) anggaran pengawasan; (4) anggaran pembelian lahan sawah (land banking); (5) sharing anggaran dengan Pemerintah Pusat/Provinsi; (6) mengefektifkan peranan swasta; (7) pemberian insentif kepada petani.

\section{UCAPAN TERIMA KASIH}

Penulis sampaikan terima kasih kepada Badan Pengawasan Keuangan dan Pembangunan (BPKP) yang telah biaya pendidikan penulis selama mengikuti Program Studi Manajemen Pembangunan Daerah, Sekolah Pasca Sarjana, Institut Pertanian Bogor.

\section{DAFTAR PUSTAKA}

Badan Perencanaan Pembangunan Daerah (Bappeda) Kota Bogor. (2015). Peraturan Daerah Kota Bogor Nomor 8 Tahun 2011 tentang Rencana Tata Ruang Wilayah Kota Bogor. Bogor: Bappeda Kota Bogor.

Badan Perencanaan Pembangunan Nasional (Bappenas). (2015). Evaluasi Implementasi Kebijakan Lahan Pertanian Pangan Berkelanjutan (LP2B). Jakarta: Bappenas.

Badan Pusat Statistik (BPS) Kota Bogor. (2016). Kota Bogor Dalam Angka Tahun 2016. Bogor: BPS Kota Bogor.

Badan Pusat Statistik (BPS) Provinsi Jawa Barat. (2013). Jawa Barat Dalam Angka Tahun 2013. Bandung: BPS Provinsi Jawa Barat.

Dewi, I. A. L., \& Sarjana, I. M. (2015). Faktor-Faktor Pendorong Alihfungsi Lahan Sawah Menjadi Lahan Non-Pertanian (Kasus: Subak Kerudung, Kecamatan Denpasar Selatan). Jurnal Manajemen Agribisnis, 3, (2).

Firmansyah, F., \& Purwadio H. (2013). Arahan Pengendalian Konversi Lahan Pertanian ke Non-Pertanian di Kabupaten Gresik. Jurnal Teknik Pomits, 2 (1).

Gevisioner, \& S., Riza, (2014). Kegagalan Perlindungan Lahan Pertanian Pangan di Provinsi Riau. Prosiding Seminar Nasional Lahan Suboptimal 2014, Palembang 26-27 September 2014. ISBN: 979-587-529-9.

Gujarati, D. (2002). Ekonometrika Dasar. Jakarta: Erlangga.

Hidayat, S. I. (2008). Analisis Konversi lahan sawah di Propinsi Jawa Timur. J-SBP, 2 (3). 
Irawan, A. (2014). Implementasi Kebijakan Pengendalian Alih Fungsi Lahan Pertanian Pangan Berkelanjutan di Kecamatan Rimba Melintang Kabupaten Rokan Hilir. JOM FISIP, 1 (2).

Keiky, Y. R. (2016). Instrumen Kebijakan Perlindungan Lahan Pertanian Pangan Berkelanjutan (Studi Proses Perumusan dan Analisa Karakteristik Instrumen Kebijakan Perlindungan Pertanian Pangan Berkelanjutan di Kabupaten Bojonegoro). Kebijakan dan Manajemen Publik, 4 (2).

Kunarjo. (2002). Perencanaan dan Pengendalian Program Pembangunan. Jakarta: Universitas Indonesia..

Kusnadi. (2002). Akuntansi Pemerintahan (Publik) Edisi ketiga. Malang: Unibraw.

Mahmudi. (2011). Akuntansi Sektor Publik. Yogyakarta: UII Press.

Mardiasmo. (2002). Akuntansi Sektor Publik. Yogyakarta: Andi Yogyakarta.

Mayasary, D. S. (2015). Analisis Perubahan Penggunaa Lahan, Pola Ruang dan Tingkat Perkembangan Wilayah di Kota Bogor. Skripsi . Institut Pertanian Bogor. Bogor.

Mintzberg, H. (1995). Strategic Process. Manila: Printice Hall.

Muljono, P., Bahtiar R., \& Warcito. (2016). Strengthening the Institusional of Farmers to Prevent Land Conversion in Cianjur Regency, West Java Province, Bogor Indonesia. Reseach Journal of Applied Sciences 11 (10): 1014-1022.

Nugraharani, D., \& Wikarta E. K. (2014). Implementasi Kebijakan Perlindungan Lahan Pertanian Pangan Berkelanjutan Dalam Mengatasi Alih Fungsi Lahan (Studi di Kabupaten Bandung, Propinsi Jawa Barat). Agric. Sci. J., 1 (4): 122-132.

Pradana, M. E. W., \& Pamungkas A. (2013). Pengendalian Konversi lahan Peetanian Pangan Menjadi Non Pertanian Berdasarkan Preferensi Petani di Kecamatan Wongsorejo, Kabupaten Banyuwangi. Jurnak Teknik Pomits, 2 (2).

Porter, M.A. (1996). What is Strategy? New York: Havard Business Review.

Putri, Z. R. (2015). Analisis Penyebab Alih Fungsi Lahan Pertanian ke Lahan Non-Pertanian Kabupaten/Kota di Provinsi Jawa Tengah 2003-2013. EKO-REGIONAL, 1 (1).
Rofiqi, D. M., Maarif, M. S., \& Hermawan A. (2016). Strategi Percepatan Pengembangan Industri Turunan Minyak Sawit Mentah (MSM) di Indonesia. Jurnal Industri Pangan, 26 (3): 246-254 (2016).

Saaty, T. L. (1993). Pengambilan Keputusan Bagi Para pemimpin, Proses hirarki Analitik untuk Pengambilan Keputusan dalam Situasi yang Kompleks. Jakarta: Pustaka Binaman Pressindo.

Salusu, J. (1996). Pengambilan Keputusan Stratejik untuk Organisasi Publik dan Organisasi Nonprofit. Jakarta: Grasindo.

Sudirman, S., Irham, S. Hartono, \& Maas, A. (2010). Analisis Faktor Penyebab dan Dampak Perubahan Penggunaan Lahan Pertanian di Pinggiran Kota Yogyakarta. J-SEP, 4 (1).

Syaifuddin, Hamire, A., \& Dahlan, (2013). Hubungan Antara Jumlah Penduduk dengan Alih Fungsi Lahan di kecamatan Somba Opu Kabupaten Gowa. Jurnal Agribisnis, 9 (2).

Sari, U. (2016). Strategi Meningkatkan Angka Harapan Hidup Melalui Alokasi Anggaran Kesehatan di Provinsi Jawa Barat. Thesis. Institut Pertanian Bogor.

Wells-Dang, A., Tu P.Q., \& Burke, A. (2016). Conversion of Land Use in Vietnam Through a Political Economy. Journal of Social Sciences and Humanities, 2 (2), 131-146.

Widayati, W., (2015). Kebijakan Perlindungan Lahan Pertanian Pangan Berkelanjutan di Kabupaten Demak. Jurnal Ilmiah Ilmu Pemerintahan, 1 (1).

Widhiantini, Dharmawan, A. H., Achsani, N. A., \& Hadi, S. (2016). Keterlibatan Para Aktor dalam Pengendalian Konversi Lahan Pertanian (Studi Kasus di Kabupaten Tabanan, Provinsi Bali). Jurnal Sosiologi Pedesaan. April 2016, 11-22.

Xie, S., \& Napasintuwong, O. (2014). Review of Rice Policies in China, Thailand and Vietnam. Exchange Master's student, Chine. ARE Working Paper No. 2557/1. 